Notes from Underground: Fugitive Ecology and the Ethics of Place

Sarah L. Lincoln

Associate Professor

Department of English

Portland State University

Box 751

Portland, OR 97201-0751

USA

sarah.lincoln@pdx.edu

Biography: Sarah L. Lincoln is associate professor of English at Portland State University, where she teaches postcolonial literature, ecocriticism, and theory. She is the author of "Petro-Magic-Realism: Ben Okri's Inflationary Modernism” (Handbook of Global Modernism, 2012) and other essays on African cinema, Caribbean fiction, excrementalism, and precarity. She is currently at work on The Idea of Gardening: Postcolonial Literature and the Ethics of Cultivation, which studies the ecological, political, and cultural work of gardening in the aftermath of colonialism.

Keywords: $\quad$ gardening; ecology; South Africa; dirt; waste; J. M. Coetzee

Abstract: In this essay, I argue for "fugitive gardening” as a form of "poaching” or "resignifying," a radical appropriation of hegemonic spaces and practices that both deconstructs the logics of mastery and hygienic possessiveness that underpin colonial culture, and articulates what we might call a fugitive ecology: a dispossession of self in relation to the environment, a refusal to conceive of land, soil, or planet in terms of property. Fugitive gardening sets itself in opposition to the prisons, camps, and forts that index South African political history, restorying place, environment, and the self as grounds for community formation, dialogue, and cooperation. Through readings of Coetzee's Life \& Times of Michael K and other examples of literary and material gardening, I show how such cultivation represents a gesture of belonging in a context where such claims are revolutionary, even treasonous; but unlike farm, fort, or prison, fugitive gardening stakes a claim to belonging without possession, home without property, and ecological care without an investment in the future. As such, gardening entails a very different understanding of self in relation to place, to nature, and to future generations, and a reconceptualization of narrative and language as representational modes. 


\section{Notes from Underground: Fugitive Ecology and the Ethics of Place}

\section{I. “Two Fragments of the European Continent Transplanted to Africa”}

European settlement in South Africa began with a garden. In April, 1652, 83 men and 8 women landed in the Cape with a mandate to establish a "refreshment station" for ships of the Dutch East India Company en route from Europe to the Indies. Cultivation of fruit and vegetables began almost immediately-though not before construction commenced (within a week of the group's arrival) on a fort. The earthen fort, susceptible to damage by wind and rain in the harsh Cape winter, would eventually be replaced by a stone castle, in the shadow of which the Company’s Garden was consolidated and expanded. Early maps of the settlement at the Cape (figure 1) show a vast blank space surrounding two clearly defined but isolated structures — the fort, and the garden — with sharp, straight lines demarcating the boundaries of European space against the "wild” and relatively unknown interior. 


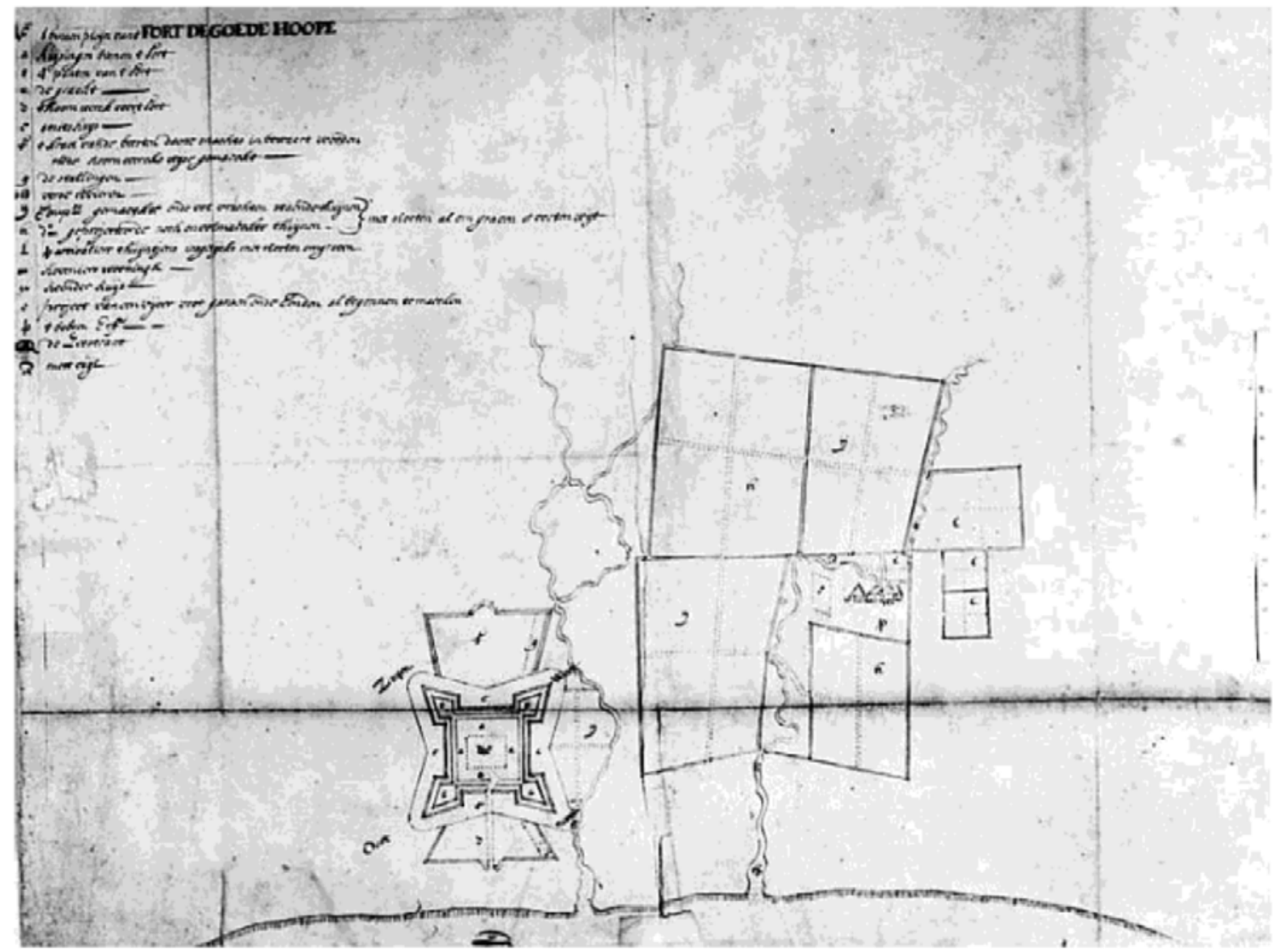

Figure 1: 1664 Dutch East India Company map showing the Fort and the Company's Garden (Beningfield, 2006, 79)

Within six years of the settlers' landing, a third key site had been added to the Cape of Good Hope’s geographical and ideological regime: on Robben Island, a small outcropping in Table Bay around 7 kilometers from the city center, a prison was established to house political offenders. Its likely first resident was Autshumato, a Gorinhaikona leader who had worked as an interpreter for the Dutch and later led a rebellion against the settlers, who was imprisoned on the Island in 1658. More famously, some three centuries later, Nelson Mandela spent 18 of his 27 years' detention on Robben Island, starting in 1964—where, perhaps less famously, he cultivated a garden "on a narrow patch of earth against the far wall” of the prison's courtyard (Mandela 1994, 425). 
The coincidence and recurrent juxtaposition of these sites, prison/fort and garden, seems an apt metonym for South Africa's colonial history—a history defined in large part by the management, organization, and control of space, and of bodies. Jennifer Beningfield calls these "two fragments of the European continent transplanted to Africa," and the complicity between the prison and the garden in the course of South African political and cultural life has many subtle and complex orientations $(2006,78)$. What they have in common, we could say, is a shared concern with dirt, with what Mary Douglas has called "matter out of place" $(2002,44)$. As she shows in her seminal study of pollution and waste, dirt indexes a concern for order, an anxiety about boundary-crossing, and a profound paranoia about being in the presence of others, exposing ourselves and our bodies to theirs. It goes without saying that these anxieties also describe the colonial and apartheid regimes' preoccupation with physical and geographical immunity, their often violent efforts to block what J.M. Coetzee calls "forms of horizontal intercourse between white and black” $(1992,97) .{ }^{1}$ The fort, the boundary fence, and the prison all represent hygienic efforts to keep things in their "proper" place, to prevent the contamination of such space (physical or symbolic) by the presence of the other: the criminal, the native, the trespasser. Sally-Ann Murray points to the "moral complicity" between racism and the cleansing imperative that defines conventional gardening: "both restrict movement across borders, and indeed the right to settlement, of supposedly undesirable migrant populations who, it is feared, would quickly take root, take over, if but given the chance” $(2006,51)$. The sharply delineated boundaries of the Company's Garden, its proximity to the Fort, and Jan Van Riebeeck's later construction of an almond hedge as a symbolic and material barrier between the Dutch settlers and the Khoikhoi, all 
testify to the ambivalence of gardening in a colonial context, and to the many ways in which humans’ relationship with nature has been complicated by-and helped complicate, in turn—-the political and social violence of colonialism.

The work of gardening in the shadow of the prison, its capacity to both reinforce power and to subtly undermine it, and the underground possibilities of gardening as a cultural and ecological practice in the aftermath of colonialism: these are the subjects with which this essay is concerned. This underground potential can be traced to the gardener's occupational interest in dirt, and to the reorientations of perception that result. In A Gardener's Year, Karel Čapek insists that the gardener's subject is, above all, the earth.

While I was only a remote and distracted onlooker of the accomplished work of gardens, I considered gardeners to be beings of a peculiarly poetic and gentle mind, who cultivate perfumes of flowers listening to the birds singing. Now when I look at the affair more closely, I find that a real gardener is not a man who cultivates flowers; he is a man who cultivates the soil. He is a creature who digs himself into the earth, and leaves the sight of what is on it to us gaping good-fornothings. He lives buried in the ground. He builds his monument in a heap of compost. If he came into the Garden of Eden he would sniff excitedly and say: "Good Lord, what humus!” I think that he would forget to eat the fruit of the tree of knowledge of good and evil: he would rather look round to see how he could manage to take away from the Lord some barrow-loads of the paradisaic soil. Or he would discover that the tree of knowledge of good and evil has not round it a nice dishlike bed, and he would begin to mess about with the soil, innocent of 
what is hanging over his head. "Where are you, Adam?” the Lord would say. "In a moment," the gardener would shout over his shoulder; "I am busy now.” And he would go on making his little bed. (2002, 37)

This delightful passage emphasizes, firstly, the "transformation of perception" that gardening entails, the gardener's interest in the dirt, soil, manure, and the spaces underground that the rest of us disdain (Harrison, 2008, 30). Lofty questions like "the knowledge of good and evil" are forgotten in the face of the practical labor of cultivation, the stooping recursive gestures and downcast eyes that define the gardener's habits. As we shall see, in this respect gardening—what Čapek would call "real gardening”—entails "a fundamental change in one's way of seeing the world, call it a phenomenological conversion” (Harrison, 2008, 30), one that (as Čapek's writings on democracy, and Mandela's own reflections on the political symbolism of gardening reveal) has revolutionary potential in a context defined by an immunitarian aversion to dirt, both physical and symbolic.

In her 1984 review of J. M. Coetzee's novel Life \& Times of Michael K, perhaps the best-known example of South African literary gardening, Nadine Gordimer (1984) famously took the author to task for what she saw as the novel's "revulsion against all political and revolutionary solutions," its studied refusal of political engagement as such. This aversion to the political conflicts, real and imagined, that for her define South African cultural life is exemplified in the protagonist's profession and, later, his selfidentification as a gardener. Early in the novel, he works as a "Gardener, grade 3(b)" for the Cape Town department of Parks and Gardens; later, having fled the war-torn city for the countryside of his mother's childhood, K begins a "life as a cultivator," first turning 
his mother's ashes into the hard soil, and later growing pumpkins and melons in a hidden patch of ground on an abandoned white farm (Coetzee, 1983, 59). As army warplanes fly high overhead, and rebel soldiers pass through on their way to the cities, $\mathrm{K}$ crouches in a makeshift burrow, creeping out at night to water his crops and resolving to stay "out of the camps, out of all the camps at the same time," living off the land and dependent on no-one (Coetzee, 1983, 182). At a pivotal moment, Michael considers emerging from his hiding spot and joining the band of revolutionaries who spend the night near his garden; at the last minute, though, he baulks, keeping still in the darkness, losing his chance to be part of their heroic endeavor. "He even knew the reason why: because enough men had gone off to war saying the time for gardening was when the war was over; whereas there must be men to stay behind and keep gardening alive, or at least the idea of gardening; because once that cord was broken, the earth would grow hard and forget her children. That was why" (Coetzee, 1983, 109).

Once again, this novel establishes the garden and the camp (the novel's term for the institutions of power: prison, reformatory, castle, asylum), gardening and war, as exemplary, and contradictory, spaces and practices of South African life. Michael K’s choice of gardening over war (on which more in a moment) represents, for Gordimer, a downward casting of the eyes, a form of abjection. "It's better to live on your knees, planting something...?” she incredulously asks, by way of conclusion. K himself seemingly confirms this reorientation of perspective when he later reflects that "the truth is that I have been a gardener, first for the Council, later for myself, and gardeners spend their time with their noses to the ground" (Coetzee, 1983, 181). So how might we understand the activity of gardening in a place like South Africa? What is its relationship 
to politics, war, and the camps that inscribe the country's physical and historical terrains? And how might we understand gardening in relation to narrative, language, and modes of representation, which Coetzee’s novel and Gordimer's review compel us to consider? As I propose here, attending to the obscured, subterranean and subversive history of gardening in South Africa helps us tell another kind of story: one that Michael K might think of as "a story with a hole in it, a wrong story, always wrong” (Coetzee, 1983, 110).

In this essay, I argue for "fugitive gardening” as a form of “poaching” or “resignifying,” a radical appropriation of hegemonic spaces and practices that both deconstructs the logics of mastery and hygienic possessiveness that underpin colonial culture, and articulates what we might call a fugitive ecology: a dispossession of self in relation to the environment, a refusal to conceive of land, soil, or planet in terms of property. As a form of counter-culture, understood in its etymological sense of care bestowed on plants and soil, fugitive gardening sets itself in opposition to the prisons, camps, and forts that index South African political history, restorying place, environment, and the self as grounds for community formation, dialogue, and cooperation. It represents, in the works and projects I study, a gesture of belonging in a context where such claims are revolutionary, even treasonous; but unlike farm, fort, or prison, fugitive gardening stakes a claim to belonging without possession, home without property, and ecological care without an investment in the future. If the logic of property is determined by a projection of the self into the future, gardens are instead "by nature impermanent creations that only rarely leave behind evidence of their existence.... Gardens are not memorials” (Harrison, 2008, 39). As such, they entail a very different understanding of self in relation to place, to nature, and to future generations, and a reconceptualization of 
narrative and language as representational modes. The literature of fugitive gardening is a literature of the "ordinary," stories defined by "slowness, tactility, and proximity, ... incremental change and the simple bonds of human co-operation” (Boehmer, 2008, 168).

\section{Gardening on the Run: Proper Space and Fugitive Tactics}

For the first settlers, the garden represented a bastion of European industry and control, marking as clearly as the walls of the Fort the boundary of civilization, the imprint of European colonial power upon the foreign landscape. In the twentieth century, apartheid's architects and urban planners similarly wielded garden space as a weapon in the ideological battle for white supremacy. Whereas the townships to which black South Africans were confined remained insistently brown, dusty, and “incomplete” (in Steve Biko's words), the growth of cities like Johannesburg and particularly “the establishment of a landscape of trees and gardens in the white suburbs" was seen by the state's city planners as "indicative of progressive policies and economic success" (Beningfield, 2006, 214).

Like all forms of colonialism, apartheid deployed its power territorially and exercised its political control through the management and allocation of space. In The Wretched of the Earth, Frantz Fanon emphasizes the ways in which freedom and unfreedom are indexed in the colony via differential access to mobility, personal space, and the ability to distance oneself from nature and its waste products:

The colonist's sector is a sector built to last, all stone and steel. It's a sector of lights and paved roads, where the trashcans overflow with strange and wonderful garbage, undreamed of leftovers. The colonist's feet can never be glimpsed.... 
They are protected by solid shoes in a sector where the streets are clean and smooth, without a pothole, without a stone. The colonist's sector is a sated, sluggish sector, its belly permanently full of good things....

The colonized's sector...the "native" quarters, the shanty towns, the Medina, the reservation, is a disreputable place inhabited by disreputable people. You are born anywhere, anyhow. You die anywhere, from anything. It's a world with no space, people are piled one on top of the other, the shacks squeezed tightly together. The colonized's sector is a famished sector, hungry for bread, meat, shoes, coal, light. The colonized sector is a sector that crouches and cowers, it's a sector on its knees... $(2005,4)$

Later, he reiterates how colonialism "hemmed in" the native subject through the designation of proper and improper space, and through the training of bodies and minds: "The first thing which a native learns," Fanon reminds us, "is to stay in his place, and not to go beyond certain limits” $(2005,52)$.

The "concept-city" of apartheid was similarly organized according to the principle of what Michel de Certeau calls "un espace propre”: space coded and constituted by power, visible to its surveillance, and repressive of "all the physical, mental and political pollutions that would compromise it” (1998, 94; see also Barnard, 2012, 72). Much of apartheid's violence, both geographical and human, stemmed from its obsessive defense of the "proper spaces" from which black subjects were prohibited, but to whose creation and maintenance they were paradoxically indispensable. This violence De Certeau would identify as "strategic," that form of rationalization that "seeks first of all to distinguish its own 'place', that is, the place of its own power and will, from an 
'environment”' (1988, 36). Strategy, and strategic thinking, depend above all on mastery of space, on the power of sight and surveillance, and on the forms of totalizing knowledge that such perspectives enable. Famously, De Certeau distinguishes the strategic operations of power from "the art of the weak," which he calls "tactics." Operating within the orbit of power and its "proper" places, tactics rely on mobility, speed, trickery, improvisation, and manipulation to achieve their ends (1988, 37). Tactical interventions always take place from within the territory of the other-that is, they are always trespassing on the "proper" space of power: "The place of a tactic belongs to the other. A tactic insinuates itself into the other's place, fragmentarily, without taking it over in its entirety, without being able to keep it at a distance” (1988, xix).

For De Certeau, the tactical arts—which he identifies as “ordinary,” in opposition to the "order" that characterizes the proper place of strategy—take many forms. Walking, cooking, guerilla warfare, speaking, all represent "clever tricks of the 'weak' within the order established by the 'strong'” $(1988,40)$. His emphasis on trespassing and poaching as elements of tactical practice invites us to consider gardening, too-particularly the kinds of "fugitive" gardening we are concerned with here—as tactical engagements with the proper spaces of apartheid South Africa. When tactics are deployed, "proper" space is redefined as contested space, an "interval of freedom" is opened up, and the self is brought into contact with embodied others (De Certeau, 1998, 255). As Nelson Mandela described, the garden, too, creates opportunities to experience "a small taste of freedom," as well as beauty, agency, and a sense of purpose in even the most constraining circumstances (1994, 426; see also Helphand, 2006). ${ }^{2}$ Like walking, gardening represents 
a "space of enunciation": a rhetoric, a "pedestrian speech act" that not only transforms spatial relations, but also assigns new forms of meaning and new kinds of stories to the spaces and material objects of the constructed order (De Certeau, 1988, 98). Gardening does not simply make use of existing spaces; it generates new places, new subjects, and new forms of relation, even if these are only fleeting or transitory.

This tactical appropriation and resignifying of space through gardening is what I hope to capture with my term "fugitive ecology." "Fugitive" suggests modes of being, knowing, and acting on the run, perpetually mobile, lacking a legal or official relationship to place, tracing an underground network of spaces and relations in and through the hidden locations of hegemonic culture. To be fugitive is not only to be elusive; it also denotes a form of oppositionality to a system predicated on the "fixing" of bodies, particularly subaltern bodies, by legal, political, and geographical institutions and apparatuses. Under apartheid, to be mobile was, by definition, to be rebellious, "out of place,” and therefore subject to the state's surveillance, pursuit, and forcible containment. Yet, in terms of apartheid's legal designation of black South Africans as "temporary sojourners" in a white country, all of these subjects inhabited a fugitive state in which they were forbidden to develop affective, legal, or cultural ties to any sites outside of the "homelands" to which they were assigned by the state. The work of what the poet Olive Senior calls "gardening on the run” both stages and critiques such dispossession, and works to contest it, by articulating new forms of belonging, environmental stewardship, and relationality that are not dependent on ownership $(2005,107)$. Fugitivity entails what Britt Rusert identifies as "a kind of radical comportment to the world, a subterranean politics and furtive insurgency" against the logics of state power, whether colonial or 
postcolonial (2013, 822). As scholars like Rusert, Moten and Harney (2013), Best and Hartman (2005), and others are helping to show, fugitivity represents a "dynamic and complex method, a practical, philosophical, and artistic method” whereby subaltern subjects make and remake their world (Rusert, 2013, 822). The fugitive gardens cultivated by vagrants, illegal city dwellers, refugees and migrants represent, following De Certeau, a resignification of space and property, as well as a reorientation of bodies, relationships (both human and environmental), and narrative form: a view of life, nature, and the politics of place from underground.

As Deleuze and Guattari show in their work, this underground, nomadic mode of being operates laterally: that is, horizontally. Its rhizomatic structure is non-hierarchical, allows for multiple points of entry and exit, and promotes affiliative rather than filiative forms of relation. They contrast the rhizomatic form against the arborescent logics of the state, which operate vertically, privilege height and vision, and insist on homogeneity and hierarchy. These contrasting orientations predicate different political forms and ideologies as well, approaches we could conceive in terms of their respective privileging of and attention to vertical and horizontal space. In his memoirs, Mandela recalls the flight that took him from Pretoria to begin his internment on Robben Island in 1964. Ever the strategist, he recalls looking down from the airplane window at the vast, open stretches of veld below and contemplating the difficulty of hiding a guerilla army in such exposed territory. When they came to the forested mountains of Matroosberg, outside Cape Town, however, he excitedly exclaimed to his comrades that "here was terrain where we could fight” (Mandela, 1994, 334). 
But as Elleke Boehmer argues, Mandela’s approach to the problem of transitioning South Africa from a colonial state to a sustainable democracy was ultimately shaped not by such long-range vision, by the kind of strategic planning and management that requires a bird's eye view, but rather by the quotidian practice of gardening, which he came to see as a model for the work of negotiation, cooperation, and humility required for political transformation. Here again, proximity to dirt played a key role. Kept in strict isolation for the first several months of their captivity, the political prisoners of Robben Island initially found that their only opportunity to communicate came each morning when they washed out their chamber pots or "ballies" at the end of the prison corridor. The guards were too repelled by the scene to maintain strict discipline, and prisoners found that they could quickly and quietly exchange news and support as they disposed of their night soil. It is clear from Mandela's memoirs that such scenes of mutual comfort, dialogue, and debate were vital to the survival of both body and spirit in confinement, and it is striking that the earliest experiences of this underground network took place around dirt. Later, the garden itself, and the cultivation of the soil, proved a fertile ground for the forging of relationships amongst the prisoners and even between prisoners and guards: warders brought compost and seeds for Mandela's plot, and he regularly supplied them in return with fresh fruits and vegetables. Thus gardening became not only a way for Mandela and his fellow prisoners to create a sense of home even in the inhospitable soil of the Island—-to tactically poach upon the proper space of the prison—but also a laboratory for the complex and important work of cultivating a democratic nation. As Boehmer shows, this "one opportunity for 'free,' constructive activity, became the primary dimension through which Mandela 
perceived that the mutual recognition of humanness—-the regenerative concept of Ubuntu—was fundamental to national transformation"; he now learned "to appreciate the value of slowness, tactility, and proximity, of incremental change and the simple bonds of human co-operation” (Boehmer, 2008, 167-8). In this respect, we could say that Mandela's years on Robben Island and, later, at Pollsmoor Prison (where he also kept a garden) effected a shift in perspective. Whereas he went into prison looking at things as the leader of a revolutionary movement—casting his eye down over the country from a ten-thousand-foot strategic vantage, contemplating the control of space as key to victory—he left prison with a new appreciation for the "grassroots" perspective, the view from below, recognizing the political value of patience, tolerance, and cooperation: that is, of the tactical significance of the "ordinary" in deconstructing the proper spaces of apartheid.

\section{III. “No Fixed Abode”: Fugitive Gardening and the Ethics of Contingency} In a photograph by David Goldblatt dated 1972 (figure 2), Ephraim Zulu of the Salvation Army is shown watering his garden at home in Central Western Jabavu, Soweto. Zulu sits on a chair in the center of the photograph, looking off to the viewer's right, holding a garden hose that spouts a jet of water beyond the left side of the photo frame. Behind him, a neighbor's house and yard are visible past a low fence, where a pair of overalls hang upside-down to dry; a woman stands near the fence, close to an outhouse building, while an excited dog is caught in motion, tail wagging, crouched as if ready to spring, near an empty clothes line. What is striking about this photograph is that, despite its pastoral title (“Ephraim Zulu of the Salvation Army watering his garden”), no soil, 
plants, or signs of cultivation are evident in the picture, apart from a few bare trees and a straggly patch of weeds along the fence line. Zulu's chair rests on bare, hard ground, and the black and white photograph's sharp contrasts evoke a sense of desolation, infertility, and ruin at odds with the caption's suggestion of a tranquil domestic scene. The house is not in view either—only an outhouse with corrugated tin roof—intensifying the feeling of disorientation and displacement. Yet Zulu's feet are firmly, if casually, planted on the ground, and his thoughtful gaze has a proprietorial air that is strengthened by his ordinary act of watering a garden. Cultivating a garden in such circumstances seems itself an act of defiance, a determination to make oneself at home in even the most inhospitable of circumstances. 


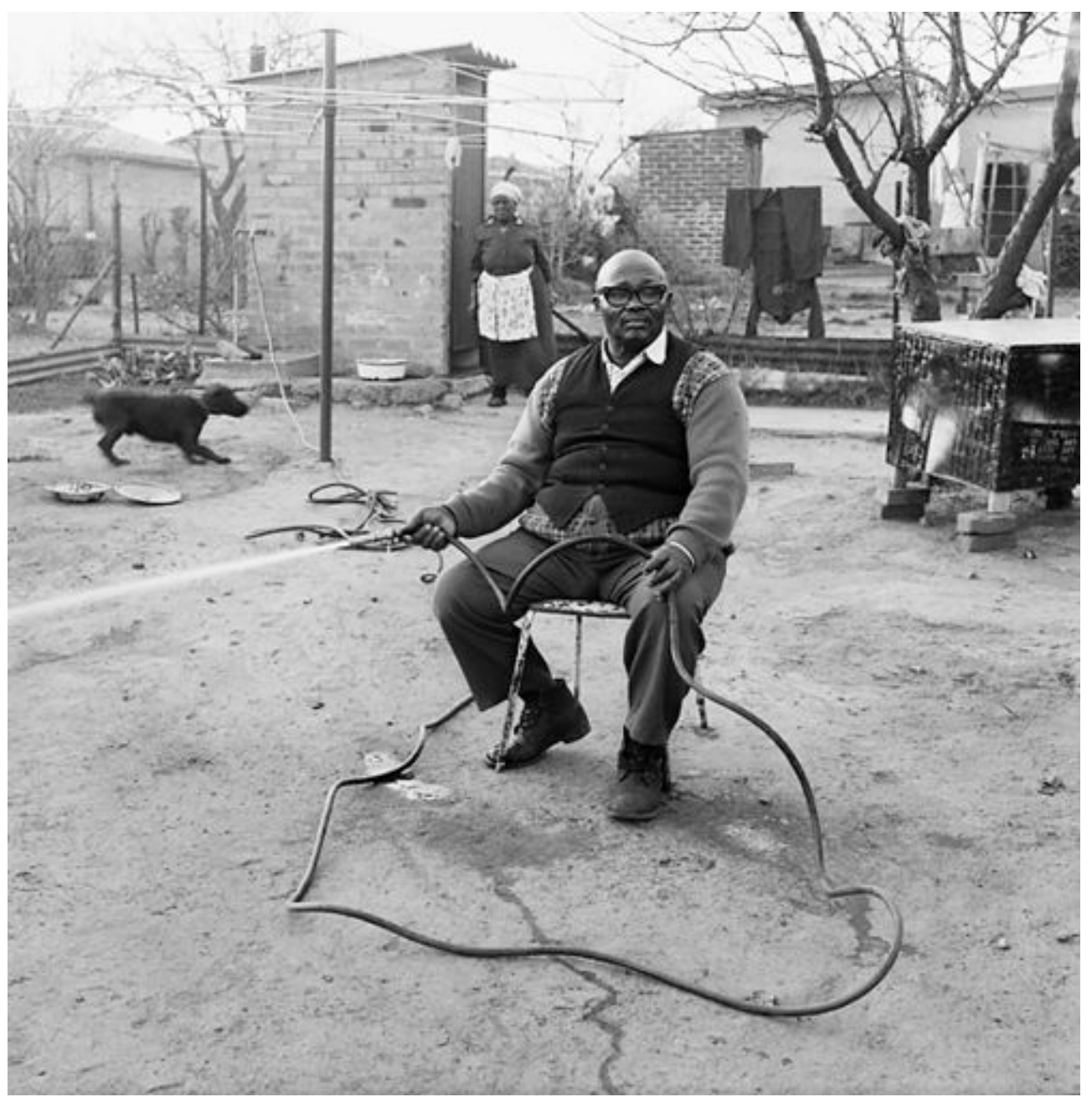

Figure 2: Ephraim Zulu of the Salvation Army Watering His Garden, 179 Central Western Jabavu, September 1972 / David Goldblatt (UCT Libraries Digital Collections)

It seems relevant that Jabavu, the area of Soweto depicted in the photograph, began as an illegal occupation of a vacant lot in Orlando West in 1944 by residents desperate for living space in the overcrowded township. The city council eventually agreed to allow the settlement as a temporary camp for 991 families, but by the time it was finally demolished in 1954 and replaced by formal housing, Jabavu and a second “temporary” settlement, Moroka, were home to 89,000 people. Though it is hard to know 
whether the residents of these squatter communities, shanty towns, or temporary camps cultivated gardens, this history of illegal and contingent occupation surely informs Ephraim Zulu's determination to nurture his own patch of green in his desolate back yard. That the garden is off screen in this image reiterates gardening's underground status, its fugitive and provisional nature, in a context where putting down roots itself represents an act of resistance to a state determined to define black subjects as temporary visitors in the white city. The barrenness of Zulu's yard—the absence of anything Western viewers might recognize as a garden, despite the photograph's title—-further testifies to the desolation of black South African urban life under apartheid, the state's reservation of access to green spaces, plants and flowers, and other natural resources to white citizens. At the same time, the photograph’s capture of an uncompleted action (“watering his garden”), and its refusal to display the results of Zulu's labor, leaves the growth status of the garden in suspension, performing a resistance to representation or interpretation that reiterates the fugitive qualities of gardening in this context.

Meaghan Posey's preliminary anthropology of gardens in Khayelitsha, a township near Cape Town, similarly emphasizes the role of gardening in fostering a sense of home and provisional belonging. The often ad hoc, miniature, or even "alternative" gardens she describes (including some that do not involve living plants, such as the "statue garden" she encounters, or Golden's garden of flowers sculpted from soda cans) serve to strengthen community bonds and a connection to place in a location where forced removals, violent evictions, and insecure land tenure are vividly recalled (Posey, 2011, 100). In their book about the gardens of homeless people in New York, Balmori and Morton argue that, despite their inherently transitory nature, these spaces "speak of a 
desire for permanence or at least an illusion of permanence” (Balmori and Morton, 1993, 1). Like these homeless gardens, the patches of earth tended by Khayelitsha's residents testify vividly to "a sense of the precariousness and fragility of nature,” and to a longing for connection, communication, and community, despite the isolating effects of poverty and violence (Balmori and Morton, 1993, 3). As each of these scholars emphasizes, gardening constitutes a speech act, a performative utterance "not in the banal sense of making 'social statements' but in the sense of militating against and triumphing over a condition of speechlessness” (Harrison, 2008, 45). Despite their geographical marginality, their tenuousness, and their small scale, the gardens of township residents articulate a powerful affirmation of humanity, agency, and hope in circumstances where these often seem to be lacking.

For Michael K, it is precisely the garden’s precariousness that sets it in opposition to the logic of “camps” that governs colonial society-a logic determined by the state's investment in futurity, permanence, and property. This orientation toward the future, and its expression in the spatial politics of property, is metonymically figured for $\mathrm{K}$ in the ubiquitous fences he encounters: around camps, marking the boundaries of farms, keeping people and animals out, or capturing them within the orbit of sovereign power. Striding across the veld, K’s exuberant sense of boundless freedom is interrupted by the fences that repeatedly impede his mobility: "He could understand that people should have retreated here and fenced themselves in with miles and miles of silence; he could understand that they should have wanted to bequeath the privilege of so much silence to their children and grandchildren in perpetuity (though by what right he was not sure); he wondered whether there were not forgotten corners and angles and corridors between the 
fences, land that belonged to no one yet. Perhaps if one flew high enough, he thought, one would be able to see" (Coetzee, 1983, 47). This quest for the "forgotten corners and angles and corridors between the fences" comes to define both the novel's plot and the plot of land Michael cultivates beside the dam on the Visagies' abandoned farm. But unlike the plot of settler colonialism—its preoccupation with survival, with what the Magistrate in Waiting for the Barbarians identifies as "how to live, how not to die, how to prolong its era"-Michael's plot, both his garden and his story, is one defined by a deliberate investment in the temporary and contingent: that is, in wastes—or in soon-tobe wastes (Coetzee, 2010, 153).

The mise-en-scène of Life \& Times of Michael K powerfully invokes Fanon’s famous description of colonial space. The near-future South Africa depicted in the novel is defined, on the one hand, by enclosure—cramped spaces, walls and fences, restrictions on movement—and, on the other, by a proliferation of wastes (Fanon's “overflow”ing trash cans) that signal the failure of such containment mechanisms. Like Fanon's colonial world, apartheid is here, at once, a landscape of excess and a terrain of hunger, a contradiction that manifests in Michael K's wasted body, discovered by soldiers amidst a proliferation of uneaten pumpkins on the farm where he gardens illegally. Ruins, remnants, and remainders here define late apartheid's landscape. He recognizes himself, too, as one of the many waste products generated by apartheid, a system depicted in the novel (as in others of Coetzee's works) as a machine for the production of waste paradoxically obsessed with hygiene:

Now they have camps for children whose parents run away, camps for people who kick and foam at the mouth, camps for people with big heads and people 
with little heads, camps for people with no visible means of support, camps for people chased off the land, camps for people they find living in storm-water drains, camps for street girls, camps for people who can't add two and two, camps for people who forget their papers at home, camps for people who live in the mountains and blow up bridges in the night. Perhaps the truth is that it is enough to be out of the camps, out of all the camps at the same time. Perhaps that is enough of an achievement, for the time being. (Coetzee, 1983, 182)

In his essay "Idleness in South Africa," Coetzee points out that the "great confinement” of early modernity — the capture and enclosure of the homeless, unemployed, socially deviant, and pathological within institutions—was symptomatic of a broader war on idleness that defined metropolitan and colonial ethnography and policy alike (1988, 20-21). Zygmunt Bauman and Mark Neocleous have argued, similarly, that waste—-wasted time, in the form of idleness; uncultivated common lands; and the "wasted lives" of those who will or cannot work—is the key characteristic of capitalist modernity, the bourgeoisie’s “obsession” (see Bauman, 2003; and Neocleous, 2011, 508). Michael's idleness, his refusal to consume, and his attachment to unclaimed or unmarked plots of land stages the novel's opposition to the biopolitical orientations of capitalist modernity. Further, Life \& Times of Michael K interrogates the historical and philosophical association of cultivation with productivity and possessive individualism (“wastes" being, precisely, uncultivated ground), showing how different kinds of relations to soil, crops, and waste persist in the interstices of capitalist accumulation. 
K’s relish of idleness (Coetzee, 1983, 115) becomes itself a form of poaching, a theft of time from a system that anxiously polices its use. In fact gardening has been associated from the start of the novel with this kind of waste: not only does Michael's work for the Cape Town Department of Parks and Gardens involve cultivating plants whose value is strictly non-utilitarian, serving only to facilitate and adorn the leisure hours of white South Africans; but the work also provides opportunities for the gardener himself to waste time, "surreptitious thefts to be enjoyed sitting on his heels before a flower-bed with the fork dangling from his fingers” (Coetzee, 1983, 115). In this respect, Michael's scandalous idleness complicates the historical association of cultivation, and the shift from pastoral to agrarian modes of production, with work: Coetzee elsewhere identifies this as "a move...in which the notion of work may be said to make its appearance in history” $(1988,34)$. But in this novel, gardening is less profoundly about labor than about idleness, an experience of time that is indifferent to the future and unmindful of the past. The state's immunitarian anxiety about security and property explains its obsessive investment in the future and its relentless patrol of vertical space, exemplified in the novel by the distant fighter jets K sees passing overhead. Michael, by contrast, inhabits time "in an unending stream," occupying "a pocket outside time” (Coetzee, 1983, 60), keeping "no tally of the days" because he "was not a prisoner or a castaway, his life by the dam was not a sentence that he had to serve out” (Coetzee, 1983, 115). The "scandal" of such idleness is precisely the challenge it presents to the ideology of accumulation, its flagrant exposure of the wastefulness and violence of capitalism's categorical imperative (Coetzee, 1988, 26; see also Coetzee, 1983, 166). 
Gardening itself thus becomes both a form of, and a response to, waste. Michael's "life as a cultivator" begins with his burying of his mother's remains, and it ends with a pile of uneaten pumpkins. It is precisely Michael's willingness to accept waste, to give himself over to wasting, as it were, that comes to define his passive opposition to the various instruments, agents, and spaces of power that seek to "fix" him. What he wastes most ostentatiously, at least by modernity's standards, is his own life. Michael's refusal to defend his own survival, to plan for or protect a legacy, to "leave his mark," becomes both his most baffling and his most environmentally provocative feature. He thinks "of himself not as something heavy that left tracks behind it, but if anything as a speck upon the surface of an earth too deeply asleep to notice the scratch of ant-feet, the rasp of butterfly teeth, the tumbling of dust” (Coetzee, 1983, 97). When he does consider a future, it is one in which his "trace"—his bones or ashes—-have been thoroughly obliterated by natural processes of waste, catharsis, and return; it is a terminal future, one imagined according to the inevitability of death and decay.

His dwelling place, constructed of wood and rock in a crevice near his garden, is deliberately temporary, precarious: "I am not building a house out here by the dam to pass on to other generations," he reminds himself, "What I make ought to be careless, makeshift, a shelter to be abandoned without a tugging at the heartstrings. So that if ever they find this place or its ruins, and shake their heads and say to each other: What shiftless creatures, how little pride they took in their work!, it will not matter” (Coetzee, 1983, 101). Though animals trespass upon his garden, nibbling young shoots and destroying burgeoning fruits, and K briefly muses "how much easier it would all be... if there were a fence” (Coetzee, 1983, 117), he ultimately rejects the act of violence 
entailed in "driving stakes into the ground, erecting fences, dividing up the land" (Coetzee, 1983, 97). Gardening is a definitively transitory practice, one that, for K, sets him in opposition to the logic of futurity that governs both the apartheid state and its revolutionary opposition, and which underwrites forms of violence, both human and environmental, in which Michael becomes entangled.

This affirmation of uncertainty and impermanence is further expressed in Michael's status as an “unbearing, unborn” creature (Coetzee, 1983, 135), one who is distinctively non-reproductive. Whereas, as Lee Edelman argues in No Future, the figural Child orients all political discourse—including, we might say, environmental discourse— toward a speculative future that he terms "reproductive futurism," Michael K's association of reproduction with violence, accumulation, and environmental destruction marks him as a queer figure, an antisocial force of negativity, in Edelman's terms (2004, 2). ${ }^{3}$ Michael's gardening represents an effort to translate this negativity into ecological practice. As Helphand argues in Defiant Gardens, “Gardens are ephemeral. Made of natural materials and in need of maintenance, their existence is short lived, their marks on the land quickly obliterated” (Helphand, 2006, x). For K, the impermanence of the garden contrasts vividly with the biopolitical imperatives of the camp, the farm, and of the apartheid state. Recalling the many generations of "children behind the wire" at the internment camp where he spent some months, $\mathrm{K}$ reflects on the relationship between the logics of survival that govern the proliferating camps, and environmental unsustainability, thinking of the "earth stamped so tight by the passage of their footsteps day after day, baked so hard by the sun, that nothing would ever grow there again” (Coetzee, 1983, 104). 
Whereas Cape Town's formal gardens stand as monuments to colonial achievement, Michael's fugitive garden is definitively temporary, existing only "for the time being” (Coetzee, 1983, 182). If fugitive gardening is a speech act, it is therefore a form of utterance not intended to stand the test of time, to testify to Michael's achievements in perpetuity. In Coetzee's novel, storytelling and survival are explicitly conjoined, as soldiers, fellow prisoners, and the medical officer under whose care he falls toward the end insist: "Where is your stake in the future?" the medical officer demands. “Do you want the story to end with you? That would make it a sad story, don’t you think? ... You don’t want to be simply one of the perished, do you? You want to live, don't you? Well then, talk, make your voice heard, tell your story!” (Coetzee, 1983, 140). Michael K’s refusal to "tell [his] story" is connected, here and throughout, to his anorexic refusal to feed his body—or, more precisely, to want food, to "want to live.” His garden is a vegetable patch, but its purpose is not to keep his or other bodies alive-it represents something other, to K, than what Hannah Arendt would regard as "labor," that is, the tasks associated with mere biological survival.

The undeniable care—perhaps even love — that Michael and the other gardeners invest in their borrowed plots of land therefore represents a form of stewardship more akin to palliative care, a love that recognizes the inevitable terminality of the gardening project and does not seek to safeguard its future. When Michael K chooses gardening over war, accumulation, and even "life," then, and when he begins his fugitive "life as a cultivator" amidst the decaying remainders of Afrikaner pastoral, he is giving himself over to waste-deliberately choosing the ruined landscapes, the rubbish, the dirt, over the proper spaces of colonial and indeed postcolonial culture. The spaces he alternately calls 
home-Huis Norenius, the boarding house, his mother's room under the stairs, the Buhrmanns' wrecked flat, his burrow on the farm, the camps-each represent a wasted space, whether serving as holding sites for the "wasted lives" of apartheid or as a monument to colonialism’s decay. Michael’s wanderings trace a landscape of ruin through and across South Africa’s “proper spaces,” exposing the ruination that attends the possessiveness and the logics of property expressed in the Fort and in Van Riebeeck's almond hedge. His wasted body, voiding itself compulsively in K's final days, itself testifies to his rejection of possession (even self-possession) as a basis for individual, social, and ecological life.

Contingency, then, becomes itself an ethical orientation in the novel. On the one hand, the contingent status of K's gardening work, subject at every turn to the possibility of natural, legal, or military cataclysm and refusing to defend itself or the land against the claims of others, defines an ecological ethics of vulnerability and dispossession. On the other, “contingent” signals (as the OED informs us) a kind of touch ("con-tangere,” touching with), an exposure to another that entails its own kind of vulnerability. This sort of embodied contact is at the heart of the novel's ecological vision. As Michael's physical intimacy with the earth intensifies, touch and smell—-those senses most immediately material—become his primary modes of interacting with his environment: "A sense less of sight than of touch, the pressure of presences on his eyeballs and the skin of his face, warned him of any obstacle. His eyes remained unfocused for hours like those of a blind person. He had learned to rely on smell too. He breathed into his lungs the clear sweet smell of water brought up from inside the earth. It intoxicated him, he could not have enough of it” (Coetzee, 1983, 115). He burrows into the earth, spends hours splayed 
out upon it, and develops an intimacy with the soil and its organic life that models, in one respect, a radical decentering of the human subject (see Head, 1998).

Just as, for Čapek, the work of gardening entails a rebellious indifference to the interpellations of power, in Michael $K$ the touch of the dirt both constitutes and catalyzes K's refusal of capture by the state and its apparatuses. Michael's instinct to "lie low" emphasizes the "underground" aspects of his life on the run. He compares himself to a mole, an earthworm—“also a gardener” (Coetzee, 1983, 182)—figures of silence and secrecy, perpetually on the move, whose fugitive rhizomatic networks facilitate their mobility, bring them into contact with other life-forms and ecosystems, but which leave no permanent trace. This "underground” ethos (his “drifting habitation” of the spaces through which he moves) further emphasizes the contrast between Michael’s fugitive gardening and the war machines that battle overhead (see Dovey, 1988, 290). Where their military energy is devoted to the capture, management, and violent defense of spacewhat De Certeau would identify as “strategic” practices-K's secret work of gardening represents a tactical manipulation and deployment of time from within the "space of the other.”

Growing an illicit garden on a white farm, and failing to maintain a "fixed abode" within the proper spaces of apartheid geography, is itself a rebellious act; moreover, K’s growing intimacy with the soil-his comparisons of himself to insects, worms, and later rocks and soil-is closely associated with his anorexic relinquishment of self, story, and subjectivity. His refusal to be fed, healed, and made meaningful by the agents of state power echoes the novel's deconstruction of property as a paradigm for conceiving, representing, and instrumentalising the earth. His con-tingent contact with the earth-a 
touch that is nonviolent, nonpossessive, and full of care-articulates a counter-cultural ethics of vulnerability that passively opposes the strategic violence of colonialism.

Fugitive ecology acknowledges the terminality that shadows all material life- the inevitability of decline, decay, decomposition, and death. K’s wasting body marks physical life itself as dirty matter, defying the efforts of doctors and other experts to rescue bodies from time. The gardener is all-too conscious of such realities, and yet still invests love, care, and labor in the stewardship of what must inevitably die. The discursive and legal frameworks that define the proper spaces of white culture- - starting with the Company's Garden-as hygienic, orderly, and productive belie the proliferating wastes on which such spaces were constructed. Dirt and other remainders index the indelible presence and proximity of the other, the "fraternity" Coetzee sees as haunting white South African imaginations, and as such marks the uncanny limit of what Antjie Krog calls the "impenetrable bunker" of colonial culture, the proper space from which whites occasionally emerged, "shooting, destroying, rubbishing, yet sharing nothing” (Krog, 2009, 266). Dirt reminds us both of our corporeal vulnerability and of the destructive "rubbishing” that results from our possessive impulses. Gardening on the run, the fugitive subjects who cultivate their tiny patches of earth in the "forgotten corners and angles and corridors between the fences” point to a new way of occupying space and responding to nature, in the ever-shrinking places of our own fragile planet.

\footnotetext{
${ }^{1}$ For more on immunity and its logics in South Africa, see also Lincoln (forthcoming).

${ }^{2}$ Helphand emphasizes the potential for gardening to foster a sense of home, hope, beauty, agency, and purpose even in contexts of violence and suffering. For a summary of these aspects, see especially the concluding chapter, "Digging Deeper: The Spirit of Defiant Gardens,” 211-248.
} 
${ }^{3}$ Edelman shows how "the fantasy subtending the image of the Child invariably shapes the logic within which the political itself must be thought" $(2004,2)$. 
References:

Balmori, Diana and Margaret Morton. 1993. Transitory Gardens, Uprooted Lives. New Haven: Yale University Press.

Barnard, Rita. 2012. Apartheid and Beyond: South African Writers and the Politics of Place. New York: Oxford University Press.

Bauman, Zygmunt. 2003. Wasted Lives: Modernity and its Outcasts. New York: Wiley. Beningfield, Jennifer. 2006. The Frightened Land: Land, Landscape and Politics in South Africa in the Twentieth Century. New York: Routledge.

Best, Stephen and Saidiya Hartman. 2005. “Introduction: Fugitive Justice.” Special issue of Representations 92 (1): 1-15.

Boehmer, Elleke. 2008. Nelson Mandela: A Very Short Introduction. New York: Oxford University Press.

Čapek, Karel. 2002. The Gardener's Year. Translated by Geoffrey Newsome. London: Modern Library.

Coetzee, J.M. 1983. Life \& Times of Michael K. New York: Penguin. 
Coetzee, J. M. 1988. "Idleness in South Africa.” White Writing: On the Culture of Letters in South Africa. New Haven: Yale University Press.

Coetzee, J.M. 1992. “Jerusalem Prize Acceptance Speech (1987).” Doubling the Point: Essays and Interviews, ed. David Attwell. Cambridge, MA: Harvard University Press.

Coetzee, J.M. 2010. Waiting for the Barbarians. New York: Penguin.

De Certeau, Michel, Luce Giard, and Pierre Mayol. 1998. The Practice of Everyday Life:

Volume 2: Living and Cooking. Translated by Timothy J. Tomasik. Minneapolis: University of Minnesota Press.

De Certeau, Michel. 1988. The Practice of Everyday Life. Translated by Steven Randall. Berkeley: University of California Press

Douglas, Mary. 2002. Purity and Danger: An Analysis of the Concepts of Pollution and Taboo. New York: Routledge.

Dovey, Teresa. 1988. The Novels of J.M. Coetzee: Lacanian Allegories. Craighall: Ad. Donker. 
Edelman, Lee. 2004. No Future: Queer Theory and the Death Drive. Durham, NC: Duke University Press.

Fanon, Frantz. 2005. The Wretched of the Earth. Translated by Richard Philcox. New York: Grove Press.

Gordimer, Nadine. 1984 (February 2). “The Idea of Gardening.” New York Review of Books. http://www.nybooks.com/articles/1984/02/02/the-idea-of-gardening/

Harrison, Robert Pogue. 2008. Gardens: An Essay on the Human Condition. Chicago: University of Chicago Press.

Head, Dominic. 1998. “The (Im)possibility of Ecocriticism.” In Writing the Environment: Ecocriticism and Literature. Edited by Richard Kerridge and Neil Sammels. London: Zed Books.

Helphand, Kenneth. 2006. Defiant Gardens: Making Gardens in Wartime. San Antonio: Trinity University Press.

Krog, Antjie. 2009. Begging to be Black. Cape Town: Random House. 
Lincoln, Sarah L. “Affirmative Precarity and the Ethics of Community.” States of Transition: The Temporalities of South African Writing. Edited by Rita Barnard and Andrew van der Vlies. Forthcoming.

Mandela, Nelson. 1994. Long Walk to Freedom. Boston: Little, Brown \& Company.

Moten, Fred and Stephane Harney. 2013. The Undercommons: Fugitive Planning and Black Study. New York: Minor Compositions.

Murray, Sally-Ann. 2006. “The Idea of Gardening: Plants, Bewilderment, and Indigenous Identity in South Africa.” English in Africa 33 (2): 45-65

Neocleous, Mark. 2011. "War on Waste: Law, Original Accumulation and the Violence of Capital.” Science and Society 75 (4): 506-528

Posey, Meaghan M. 2011. Intimate Infrastructure: Garden Making As A Spatial Tactic In Post-Apartheid Khayelitsha, South Africa. Master in Landscape Architecture Thesis. University of Colorado, Denver. http://gateway.proquest.com/openurl?url_ver=Z39.882004\&res_dat=xri:pqdiss\&rft_val_fmt=info:ofi/fmt:kev:mtx:dissertation\&rft_dat=xri:pq diss:1507315 
Rusert, Britt. 2013. "Delany's Comet: Fugitive Science and the Speculative Imaginary of Emancipation.” American Quarterly 65 (4): 799-829

Senior, Olive. 2005. “Gardening on the Run.” Gardening in the Tropics. Toronto: Insomniac. 